\title{
GENOME-WIDE ASSOCIATION STUDY: A GENOMIC RESORT TO TACKLE THE MENACE OF ANTIMICROBIAL RESISTANCE
}

\author{
A. KOUR AND S. M. DEB* \\ Animal Genetics and Breeding Division \\ ICAR-National Dairy Research Institute (Deemed University) \\ Karnal- 132 001, Haryana, India
}

\begin{abstract}
Antimicrobial resistance (AMR) has been identified as a serious calamity having widespread ramifications for animal, human as well as environmental health. For tackling AMR, along with antibiotic stewardship and measures for controlling and preventing diseases, there is a need to look into the genetic aspect of diseases. Disease resistance is a highly complex trait with various underlying causative variants, genes and biological pathways responsible for it. So, a deeper look into the genomic information could offer insights for selecting animals for disease resistance. A Genome-wide Association Study (GWAS) is well suited for this purpose as it brings to the fore, genomic variants and regions associated with disease resistance by exploiting variability among the individuals. Once the actual causative mutations are identified for important animal diseases by GWAS, selection and consequently, raising of animals for resistance against a disease will become a lot easier. This in turn, will contribute to lesser reliance on antimicrobials and hence, could serve as an important and effective weapon to root out the phenomenon of antimicrobial resistance.
\end{abstract}

Key words: Antimicrobial resistance, Disease resistance, GWAS

Animal health is an indispensible component encompassing production, reproduction and animal welfare aspects (http://www.fao.org/ animal-health/en/; Wolfenson et al., 2015; https:// awionline. Org /sites/default/files/ uploads/documents/FA-AWI-AnimalHealth-Welfare-Report-04022018.pdf). Anti-microbial drugs have served as an important pillar of animal health support systems by playing an important role in therapeutics, metaphylactics, prophylactics and growth promotion (Woolhouse et al.,
2015). Poor quality antibiotics, ill-trained veterinary practitioners and rising demand for meat are some of the factors which have further pushed the reliabilities on antimicrobial drugs (Clifford et al., 2018; Wegener, 2012; Walia et al., 2019). All this has led to the emergence of the phenomenon of antimicrobial resistance (AMR) which has been dubbed as a worldwide calamity (Kunin, 1993) with far reaching implications on animal, human as well as environmental health (Taneja and Sharma, 2019). In fact,

${ }^{*}$ Corresponding Author 
combating the menace of antimicrobial resistance was an important reason behind the genesis of 'One Health' concept which aims at harmonisation of strategies and policies directed at humans, animals as well as environment and adopting a coordinated as well as integrative approach for the improvement of health of all (https:// www.oie.int/en/for-the-media/editorials/ detail/article/one-health/; Woolhouse et al., 2015; Marquardt and Li, 2018).

The grim scenario regarding indiscriminate use of antibiotics is depicted by the fact that more than $70 \%$ of all the antimicrobial drugs sold in the world are used on food animals (Boeckel et al., 2019). This further led to the proposition that livestock are acting as repositories of resistance genes (Woolhouse et al., 2015) and these genes are entering humans through the food chain, thus prolonging the illness, frequent bouts of illness, emergence of highly resistant strains of microorganisms (Kumarasamy et al., 2010) and consequently, failure of treatment (https://www.who.int/foodsafety/ areas_work/antimicrobial-resistance/ amrfoodchain/en/). However, a recent study has demonstrated that the gene transfer is in fact, happening in the other direction as well and the resistant genes are also getting introgressed from humans to other species (Richards et al., 2019).

India and China have been reported as the global hotbeds for AMR in livestock owing to the large livestock population and burgeoning demand for livestock products (Boeckel et al., 2019; https://www. reactgroup.org/wp-content/uploads/2018/ 11/Antimicrobial_Resistance_in Food_Animal_Production_India_
Overview_2018_web.pdf; Laxminarayan and Choudhary, 2016). A study collating 901 point-prevalence surveys revealed startling figures: the proportion of antimicrobial drugs with resistance higher than 50\% (P50) in low and medium income countries like India and China, increased dramatically in case of chickens (173\%) and pigs (161\%) between 2000 and 2018 (Boeckel et al., 2019). It has made the treatment of sick animals and production of enough meat to satisfy the demands of population, increasingly difficult (Bengtsson and Greko, 2014). The reported estimates peg the direct costs of individual diseases to be $35-50 \%$ of the total turnover in the developing countries (Bennett, 2003).

\section{Selection for disease resistance in livestock}

Besides environmental influences, the resistance of an animal to diseases is also dictated by the genetic makeup of the individual. Long term and sustainable resistance in a population against a particular disease is often achieved by exploiting existing genetic variability among the individuals for resistance against that disease which would also complement other environmental interventions (Gibson and Bishop, 2005; Bishop, 2010). Selection for disease resistance is not a new concept and the awareness regarding this, dawned on the animal breeders long back. Since then, the research was targeted at selection for improving various livestock species against particular diseases - nematodiasis in sheep (Stear et al., 1997; Bisset and Morris, 1996), mastitis in cattle (Heringstad et al., 2000), enhanced immune responsiveness in pigs (Mallard et al., 1998; Wilkie and Mallard, 2000) and avian lymphoid leucosis complex 
and Marek's disease in chickens (Cole, 1968). In this respect, various studies have also emphasised on the lower susceptibility of indigenous Zebu cattle against diseases and parasitic infestations, as compared to exotic cattle breeds (Vordermeier et al., 2012; https://pdfs.semanticscholar.org/ $1 \mathrm{dfe} / 8 \mathrm{cc} 8349 \mathrm{dfe} \quad 0 \mathrm{c} 5 \mathrm{e} 3040167 \mathrm{a} 2 \mathrm{f}$ 84346463211 e.pdf) and this has been attributed to the variability in the genetic makeup (http://www-naweb.iaea.org/nafa/ a p h / crp/aph-i m proving - an imalproductivity.html). The traditional approaches for breeding of livestock for disease resistance included: selecting sires and/or animals successively in each generation (for lesser disease incidences) for future breeding (Heringstad et al., 2007; Tsairidou et al., 2019) and identification of MHC antigens involved in immune responses and selecting individuals with a particular antigen indicative of resistance to a disease (Bearse et al., 1963; Lamont, 1998). With the advent of advanced molecular techniques, expression profiling was carried out to explore the candidate genes responsible for disease resistance (Abdul-Careem et al., 2007; Taylor et al., 2008; Fonseca et al., 2009) and further association studies were undertaken in a quest to identify DNA markers for selection by targeting the association between candidate genes polymorphisms and indicators of resistance and/or susceptibility for specific diseases (Ibeagha-Awemu et al., 2008; Wu et al., 2008; Ogorevc et al., 2009; Verschoor et al., 2010).

\section{Genomics wave in animal breeding}

Since early 2000s, a new 'genomics era' has dawned in animal breeding with the emergence of high-throughput genotyping platforms and next-generation sequencing technologies and the costs of genotyping are also falling considerably (Eggen, 2012). As a result of this, selection of animals has also witnessed an evolution from phenotypic selection to marker-assisted selection and consequently, to genomic selection. The underlying principle in genomic selection is that if markers throughout the genome are targeted for selection, there is higher chance of accounting for most of the genetic variance for a trait as the quantitative trait loci (QTL) or underlying causative mutation responsible for the trait would be in linkage disequilibrium (LD) with at least one marker (Meuwissen et al., 2001; Goddard and Hayes, 2007). Also, there is a growing realisation that breeding animals for major disease resistance genes is effective but these genes are highly vulnerable to breakdown with rapid changes in the pathogenic races and that the breeding objective should shift towards understanding the genetic architecture of many diffused minor genes. This necessitates genomicassisted breeding for quantitative resistance using genomic prediction models and selection (Poland and Rutkoski, 2016). Unravelling the genetic architecture of a disease by identification and validation of genomic regions conferring disease resistance would facilitate the propagation of resistant animals through genomic selection (Yuan et al., 2018). In this context, a Genome-wide Association Study (GWAS) is a very useful tool to improve the accuracy of genomic selection by shedding light on the identified genetic markers, putative genes and QTL regions underlying the complex mechanisms of disease resistance 
and hence, act as an initial screening tool (Meredith et al., 2012; Zhang et al., 2014a; Lee et al., 2015b).

\section{Genome-wide Association Study}

Till date, more than 10,000 loci have been identified for common heritable human diseases and traits using a highly powerful approach - Genome-wide Association Study (GWAS), which is a hypothesis-free tool to reveal the associations between genomic regions (SNPs, genes, QTLs) and traits (diseases and quantitative traits) (Duncan and Brown, 2018). The GWAS have also been widely employed in various livestock populations to explore the genetic variants related to economic traits viz. production, functional and conformation traits (Cole et al., 2011; Wang et al., 2018; Gerlando et al., 2019). The principle behind a Genomewide Association Study is to detect the markers throughout the genome (usually SNPs) having a significant $p$-value by testing their association with the trait of interest (Zhang et al., 2014a; Schmid and Bennewitz, 2017).

Identification of Quantitative Trait Nucleotide (QTN) or underlying causative mutation is the end product desired from genomics so as to make the selection based on genomic information more precise as well as cost-effective (Weller and Ron, 2011). GWAS makes it a lot easier by casting light on the potential regions where to look up for the causative variants by finemapping (Weller, 2016). Also, the accuracy of genomic breeding values (GEBV) obtained based on GWAS results are higher than those obtained solely on the basis of whole genome prediction (Zhang et al., 2014b).
Genomic data obtained using various SNP arrays usually serves as the raw material for GWAS although the accuracy of results depends on the marker density used, effective population size, heritability and genetic architecture of the trait (Matukumalli et al., 2009; Liu et al., 2017; Zhang et al., 2019). In a GWAS, trait associations with SNP markers could be estimated either with phenotype of the trait (Bouwman et al., 2011; Yodklaew et al., 2017) or with its pseudo-phenotype, which is a projection closest to the genotypic estimate (Liu et al., 2004; Garrick et al., 2009).

\section{Quality control in GWAS}

A basic requisite before determining actual association between genomic and phenotypic information in a GWAS is the quality control (QC) of the genomic data (Turner et al., 2011). For QC, the trimming of genomic data is done based on certain criteria usually, call rate (CR), minor allele frequency (MAF) and test of HardyWeinberg equilibrium (HWE) (Liu et al., 2018). Call rate is an important criterion for QC of both SNPs and samples (Jiang et al., 2010). For a given SNP, CR is defined as the percentage of individuals for which the information of that SNP (called SNP) is not missing and sample call rate excludes individuals with higher percentage of missing genotype data out of the total typed SNPs (Reed et al., 2015). Most of the studies set the pre-defined threshold of $\geq 90 \%$ for SNP as well as sample filtering (Meredith et al., 2012; Wu et al., 2014; Abdoli et al., 2018). Another important criterion is minor allele frequency. The MAF is defined as the frequency of less common allele at a locus in the population and most of the studies 
employ $\geq 0.05$ as cut-off value for SNP to be included for further analysis (Fan et al., 2011; Nazari-Ghadikolaei et al., 2018). Violation of Hardy-Weinberg equilibrium is expected due to differing population structure and genotyping error (Reed et al., 2015). So, the SNPs showing departure from HWE (usually $p$ value $\geq 10^{-6}$ ) are not included in the final analysis (Jiang et al., 2010; Lee et al., 2015b).

\section{Statistical analysis in GWAS}

For testing association between SNP markers and the dependent trait, two types of association models are used: Single-marker models and Multi-marker models

Single marker models: Here, one SNP is fitted at a time in the model with the null hypothesis of no association between SNP and the trait (Schmid and Bennewitz, 2017). In the context of GWAS, single-marker model approach is more commonly utilised (Balding, 2006). However, due to multiple tests being performed simultaneously, there is a serious inflation of type-I error, which can lead to thousands of false-positive associations even when none is actually associated with the trait (Zeng et al., 2015). Due to this, another problem of 'Beavis effect' crops up, which is the over estimation of the true QTL effects of statistically significant associations (Beavis, 1994; Weller, 2016).

A possible way out to handle the problem of multiple comparisons in GWAS include Bonferroni correction and false discovery rate (FDR). Bonferroni correction gives a conservative estimate by setting strict significant thresholds to find false positives. Here, the adjusted p-value is estimated as: $\alpha / \mathrm{m}$ where, $\alpha=$ significance level set (typically 0.05 ) and $\mathrm{m}=$ number of markers used. However, it is not able to account for most of the genetic variance for a trait as most of the SNPs fail to meet the significance criterion (Zeng et al., 2015). On the other hand, false discovery rate assesses the number of associations reaching significance thresholds, which are actually false positives (Benjamini and Hochberg, 1995). FDR gives a q-value threshold as the proportion of significant features which turn out to be false positives (Storey and Tibshirani, 2003). It is calculated as FDR = $\mathrm{m} \alpha / \mathrm{i}$ where, $\mathrm{m}=$ number of markers (SNPs) tested for a trait, $\alpha=p$-value or level of significance utilized, $\mathrm{i}=$ no. of cases in which the null hypothesis got rejected at that p-value (Schmid and Bennewitz, 2017).

Multi-marker models: In another attempt to address the problem of multiple testing and number of SNPs disproportionately exceeding the sample size, multi-marker models were devised which though originally developed for genomic selection (Meuwissen et al., 2001), became highly popular in GWAS studies as well (Sahana et al., 2011; Goddard et al., 2016). The basic principle of multi-marker models is that all SNPs are fitted simultaneously as random effects. Based on the assumption regarding the distribution of marker effects, different types of multi-marker models are used (Schmid and Bennewitz, 2017).

The SNP-BLUP models and GBLUP models invoked the infinitesimal model of genetic variation to estimate marker effects, assuming a normal distribution with a small variance for each marker. The former 
employs SNP-SNP relationship matrixes (Lee et al., 2015b) while the latter employs genomic relationship matrix (GRM) to generalise marker effects even for individuals without genotypic data (Aguilar et al., 2010; Wang et al., 2012).

Conversely, several Bayesian models have been proposed which assume unequal variances across SNPs and employ models with differing prior distribution of SNP variances. Bayes A model assumed a thicker $\mathrm{t}$-tailed distribution of marker effects while Bayes B considered a t-distribution for only a fraction of SNPs which were assumed to contribute towards the variance of a trait (Meuwissen et al., 2001). Bayes C considers two SNP fractions- one with a larger variance and another with a smaller variance for the trait and hence, assuming two different $\mathrm{t}$ distributions for each (Verbyla et al., 2009; Verbyla et al., 2010). Bayes $\mathrm{R}$ assumes a mixture of normal distribution for certain effective SNPs and allows few SNPs with large effects (Erbe et al., 2012). Bayesian LASSO assumes different variances for residual and SNP effects (Legarra et al., 2011).

The SNPs which are found to be statistically significant in GWAS are represented in a Manhattan plot which is a scatter plot having genomic coordinates in $\mathrm{X}$-axis and negative logarithm of $\mathrm{p}$-value for association (between SNP and trait) on Y-axis (https:// en.wikipedia.org/wiki/Manhattan_plot). Another graphical representation of GWAS results (particularly, association models for diseases) is a QQ plot in which the observed and the expected $\mathrm{p}$-values are plotted from a theoretical Chi-square distribution (Ehret, 2010).

\section{GWA studies for disease resistance in various livestock species}

A successful GWAS was first reported in 2002 in a human study for myocardial infarction (Ozaki, 2002). This was soon followed up by a landmark study in 2005 for screening genetic variants related to agerelated macular degeneration in humans (Klein et al., 2005). While in humans, the GWAS were directed mostly on disease susceptibility and studies on height (Hill, 2012), in animals, these studies took a more diversified approach to study economic quantitative traits in addition to disease resistance (Cole et al., 2011; Sahana et al., 2014). Selecting animals which are resistant against particular diseases improves the overall production, reproduction, health and welfare prospects (Rexroad et al., 2019).

In cattle, mastitis is one of the most commonly studied diseases based on GWAS data due to its multi-factorial nature and huge economic implications (Meredith et al., 2013; Sahana et al., 2014; Wang et al., 2015). Somatic cell count (Kurz et al., 2018; Welderufael et al., 2018) and somatic cell score (Meredith et al., 2012; Wang et al., 2015) are commonly used as indicators of mastitis susceptibility in most of the studies. Similarly, studies have been conducted to identify important markers and loci associated with infectious diseases like tuberculosis and foot and mouth disease (Bermingham et al., 2014; Alpay et al., 2014; Lee et al., 2015a). In small ruminants like sheep and goat, nematode resistance is often the targeted trait through GWAS (Wilkie et al., 2017; Zvinorova, 2017). Pigs, being mostly afflicted with respiratory inflictions, have been evaluated genome- 
Table 1. GWAS carried out in different livestock species for disease resistance

\begin{tabular}{|c|c|c|c|c|}
\hline Species & Breed & $\begin{array}{l}\text { Diseases or traits } \\
\text { considered }\end{array}$ & $\begin{array}{l}\text { Number of significant } \\
\text { SNPs and /or } \\
\text { candidate genes/ } \\
\text { QTL region reported }\end{array}$ & References \\
\hline & Holstein & $\begin{array}{l}\text { Foot and mouth } \\
\text { disease }\end{array}$ & $\begin{array}{l}11 \text { SNPs } \\
\text { MYO18B and SEZ6L genes }\end{array}$ & $\begin{array}{l}\text { Lee } \text { et al., } \\
2015 \mathrm{a}\end{array}$ \\
\hline & $\begin{array}{l}\text { Holstein- } \\
\text { Friesian }\end{array}$ & Bovine tuberculosis & $\begin{array}{l}3 \text { SNPs } \\
\text { SLC6A6 gene }\end{array}$ & $\begin{array}{l}\text { Finlay et al., } \\
2012\end{array}$ \\
\hline & Holstein & Johne's disease & $\begin{array}{l}\text { SLCO6A1, ILI2B, TIMD4, } \\
\text { C5, CD44 genes }\end{array}$ & $\begin{array}{l}\text { Alpay et al., } \\
2014\end{array}$ \\
\hline & Holstein & Mastitis & 117 SNPs and 27 QTLs & $\begin{array}{l}\text { Kurz et al., } \\
2018\end{array}$ \\
\hline & $\begin{array}{l}\text { Holstein- } \\
\text { Friesian }\end{array}$ & Tuberculosis & PTPRT and MYO3B genes & $\begin{array}{l}\text { Bermingham } \\
\text { et al., } 2014\end{array}$ \\
\hline \multirow[t]{5}{*}{ Cattle } & $\begin{array}{l}\text { Chinese } \\
\text { Holstein }\end{array}$ & Mastitis & $\begin{array}{l}48 \text { SNPs TRAPPC9 } \\
\text { and ARHGAP39 genes }\end{array}$ & $\begin{array}{l}\text { Wang et al., } \\
2015\end{array}$ \\
\hline & $\begin{array}{l}\text { Canadian } \\
\text { Holsteins }\end{array}$ & $\begin{array}{l}\text { Immune response } \\
\text { traits }\end{array}$ & $\begin{array}{l}\text { BoLA-DQ, BoLA-DR, } \\
\text { BoLA-NC1, BoLA-DQ, } \\
\text { galectins } 1,2 \text { and } 3, \\
\text { BCL2 and â-defensin genes }\end{array}$ & $\begin{array}{l}\text { Thompson- } \\
\text { Crispi et al., } \\
2014\end{array}$ \\
\hline & U.S. Jersey & Ketosis & $\begin{array}{l}\text { TTLL7, ARAP2, CD207, } \\
\text { SPAST, FERMT2, BMP4, } \\
\text { DDHD1, XDH genes }\end{array}$ & $\begin{array}{l}\text { Gaddis et al. } \\
2018\end{array}$ \\
\hline & $\begin{array}{l}\text { Canadian } \\
\text { Holstein }\end{array}$ & Subclinical ketosis & $\begin{array}{l}\text { SLC4A4, FRAS1, GC, } \\
\text { FRAS 1, CXCL8, RASSF6, } \\
\text { FAM47E genes }\end{array}$ & $\begin{array}{l}\text { Nayeri et al., } \\
2019\end{array}$ \\
\hline & $\begin{array}{l}\text { Gir X } \\
\text { Holstein } \\
\text { crossbreds }\end{array}$ & Tick infestation & $\begin{array}{l}\text { TREM1, TREM2, CD83, } \\
\text { MYO5A, TREML1 and } \\
\text { PRSS16 genes }\end{array}$ & $\begin{array}{l}\text { Otto et al. } \\
2018\end{array}$ \\
\hline \multirow[t]{2}{*}{ Sheep } & $\begin{array}{l}\text { Scottish } \\
\text { Blackface }\end{array}$ & Nematode resistance & $\begin{array}{l}12 \text { SNPsIL23R, } \\
\text { RORC2 and TBX21 genes }\end{array}$ & $\begin{array}{l}\text { Wilkie et al., } \\
2017\end{array}$ \\
\hline & Corriedale & Inherited rickets & DMP1 & $\begin{array}{l}\text { Zhao et al., } \\
2011\end{array}$ \\
\hline
\end{tabular}


Cont. Table 1.

\begin{tabular}{|c|c|c|c|c|}
\hline Species & Breed & $\begin{array}{l}\text { Diseases or traits } \\
\text { considered }\end{array}$ & $\begin{array}{l}\text { Number of significant } \\
\text { SNPs and /or } \\
\text { candidate genes/ } \\
\text { QTL region reported }\end{array}$ & References \\
\hline & $\begin{array}{l}\text { Scottish } \\
\text { Blackface }\end{array}$ & Nematode resistance & 3 SNPs & $\begin{array}{l}\text { Riggio et al., } \\
2013\end{array}$ \\
\hline & Texel & Foot rot & 7 SNPs & $\begin{array}{l}\text { Mucha et al., } \\
2015\end{array}$ \\
\hline \multirow[t]{2}{*}{ Goat } & $\begin{array}{l}\text { Breed not } \\
\text { specified }\end{array}$ & $\begin{array}{l}\text { Gastrointestinal } \\
\text { parasites }\end{array}$ & $\begin{array}{l}15 \text { SNPs ORC5, RELN } \\
\text { and NALCN genes }\end{array}$ & $\begin{array}{l}\text { Zvinorova, } \\
2017\end{array}$ \\
\hline & Creole & $\begin{array}{l}\text { Gastrointestinal } \\
\text { nematodes }\end{array}$ & 13 QTLs & $\begin{array}{l}\text { La Chevrotiere } \\
\text { et al., } 2012\end{array}$ \\
\hline \multirow{3}{*}{ Pig } & $\begin{array}{l}\text { Chinese } \\
\text { Erhualian } \\
\text { pigs }\end{array}$ & $\begin{array}{l}\text { Swine respiratory } \\
\text { disease }\end{array}$ & $\begin{array}{l}\text { CXCL6, CXCL8, KIT } \\
\text { and CTBP2 genes }\end{array}$ & $\begin{array}{l}\text { Huang et al., } \\
2016\end{array}$ \\
\hline & Landrace & $\begin{array}{l}\text { Respiratory disease } \\
\text { immune capacity }\end{array}$ & $\begin{array}{l}5 \text { QTLs } \\
18 \text { QTLs }\end{array}$ & $\begin{array}{l}\text { Okamura } \\
\text { et al., } 2012\end{array}$ \\
\hline & $\begin{array}{l}\text { Large Whit } \\
\text { pigs }\end{array}$ & $\begin{array}{l}\text { Metabolism and } \\
\text { protein related traits } \\
\text { leukocyte traits }\end{array}$ & $\begin{array}{l}13 \text { SNPs } \\
11 \text { SNPs }\end{array}$ & $\begin{array}{l}\text { Bovo et al., } \\
2019\end{array}$ \\
\hline \multirow{4}{*}{ Chicken } & & $\begin{array}{l}\text { Salmonella pullorum } \\
\text { infection }\end{array}$ & 43 SNPs & $\begin{array}{l}\text { Xiao et al., } \\
2019\end{array}$ \\
\hline & & $\begin{array}{l}\text { New Castle disease } \\
\text { virus }\end{array}$ & $\begin{array}{l}2 \text { SNPs } \\
\text { ROBO2 gene }\end{array}$ & $\begin{array}{l}\text { Luo et al., } \\
2013\end{array}$ \\
\hline & & Marek's disease & $\begin{array}{l}\text { Regions on chromosomes } \\
2,3,49,15,18 \text { and } 21\end{array}$ & $\begin{array}{l}\text { Wolc et al., } \\
2013\end{array}$ \\
\hline & & $\begin{array}{l}\text { Heterophil/ } \\
\text { lymphocyte ratio traits }\end{array}$ & $\begin{array}{l}15 \text { SNPs CARD11, } \\
\text { BRIX1 and BANP }\end{array}$ & $\begin{array}{l}\text { Zhu et al., } \\
2019\end{array}$ \\
\hline
\end{tabular}

wide for important markers and genomic regions related to it (Huang et al., 2016) while in poultry, markers and QTL regions have been identified for various infectious diseases using GWAS (Luo et al., 2013; Wolc et al., 2013; Xiao et al., 2019).

These days, researchers are going for meta- analysis combining the information from earlier available GWA studies to draw more concrete and substantial conclusions (Minozzi et al., 2012; Blaj et al., 2018). A review of GWAS for disease resistance in various livestock species has been presented in Table 1. 


\section{GWAS and the issue of antimicrobial resistance}

Tackling the menace of antimicrobial resistance requires a multi-pronged strategy which should not only be targeted at antibiotic stewardship and infection control measures (Toner et al., 2015) but also at exploring the variability at the genomic level for resistance against various diseases (Caballero et al., 2018; Farhat et al., 2019). However, genetics of disease resistance is a complex trait determined by multiple factors and interactions (https://www.nature.com/ scitable/topicpage/complex-diseasesresearch-and-applications-748/), which are not fully accounted by linkage studies (https://en.wikipedia.org/wiki/Genomewide_association_study). A GWAS is a more powerful way to trace out the genomic variants and locations where the key to resistance against a disease may be hidden (Hirschhorn and Daly, 2005). Several GWAS directed at various diseases in livestock have already been undertaken and useful information has been obtained (Sharma et al., 2015). Selection of animals

\section{REFERENCES}

Abdoli R, Mirhoseini SZ, Zadeh NGH, Zamani P and Gondro C, 2018. Genome-wide association study to identify genomic regions affecting prolificacy in LoriBakhtiari sheep. Anim Genet, 49(5): 488491

Abdul-Careem MF, Hunter BD, Parvizi P, Haghighi HR, Thanthrige-Don N et al., 2007. Cytokine gene expression patterns associated with immunization against Marek's disease in chickens. Vaccine, 25(3) : 424-432 against various diseases based on GWAS results could be an important component of fight against antimicrobial resistance and would surely play its part in spelling doom for it (Chen et al., 2015).

\section{Conclusion}

With the farming becoming more intensive and profit-oriented, the incidences and frequency of diseases are going to rise. This, accompanied by indiscriminate antimicrobial use and consequent emergence of highly resistant organisms is going to make the matters worse. In this scenario, relying solely on prophylactic and therapeutic measures (or any other environmental manipulation) is not enough and long-term sustainable resistance against diseases is possible only through the improved genetics of animals. In this context, genome-wide association studies could be of great help in pinpointing the underlying genetic causes of disease resistance and/or susceptibility and hence, could pave the way for selection of resistant animals in future.

Aguilar I, Misztal I, Johnson D, Legarra A, Tsuruta S et al., 2010. Hot topic: A unified approach to utilize phenotypic, full pedigree, and genomic information for genetic evaluation of Holstein final score. J Dairy Sci, 93 (2): 743-752

Alpay F, Zare Y, Kamalludin MH, Huang X, Shi X et al., 2014. Genome-wide association study of susceptibility to infection by Mycobacterium avium subspecies paratuberculosis in Holstein cattle. PLoS 
ONE, 9(12): e111704. doi:10.1371/ journal.pone. 0111704

Balding D, 2006. A tutorial on statistical methods for population association studies. Nat Rev Genet, 7(10): 781-791

Bearse GE, Becker WA and Hamilton CM, 1963. Resistance and suscpetibility to the Avian Leucosis Complex in chickens. Poult Sci, 42(1): 110-121

Beavis WD, 1994. The power and deceit of QTL experiments: lessons from comparative QTL studies. Proceedings of the Forty-Ninth Annual Corn and Sorghum Industry Research Conference, American Seed Trade Association, Chicago, pp250-266

Bengtsson B and Greko C, 2014. Antibiotic resistance- consequences for animal health, welfare, and food production. Ups J Med Sci, 119(2): 96-102

Benjamini Y and Hochberg Y, 1995. Controlling the false discovery rate: A practical and powerful approach to multiple testing. J Royal Stat Society, 57(1): 289-300

Bennett R, 2003. The 'Direct Costs' of livestock disease: The development of a system of models for the analysis of 30 endemic livestock diseases in Great Britain. J Agric Econ, 54(1): 55-71

Bermingham ML, Bishop SC, Woolliams JA, Wong RP, Allen AR et al., 2014. Genome-wide association study identifies novel loci associated with resistance to bovine tuberculosis. Heredity, 112(5): 543-551

Bishop SC, 2010. Disease resistance: Genetics. In: Encyclopedia of Animal Science (Pond WG, Bell AW, eds). Marcel Dekker Inc (New York), pp288-290

Bisset SA and Morris CA, 1996. Feasibility and implications of breeding sheep for resilience to nematode challenge. Int J Parasitol, 26 (8-9): 857-868
Blaj I, Tetens J, Preuû S, Bennewitz J and Thaller G, 2018. Genome-wide association studies and meta-analysis uncovers new candidate genes for growth and carcass traits in pigs. PLoS ONE, 13(10): e0205576, https:// doi.org/10.1371/journal.pone. 0205576

Boeckel TPV, Pires J, Silvester R, Zhao C, Song J et al., 2019. Global trends in antimicrobial resistance in animals in low- and middleincome countries. Science, doi: 10.1126/ science.aaw1944

Bouwman AC, Bovenhuis H, Visker MHPW and Arendonk JAM, 2011. Genome-wide association of milk fatty acids in Dutch dairy cattle. BMC Genet, doi: 10.1186/14712156-12-43

Bovo S, Mazzoni G, Bertolini F, Schiavo G, Galimberti G et al., 2019. Genome-wide association studies for 30 haematological and blood clinical-biochemical traits in Large White pigs reveal genomic regions affecting intermediate phenotypes. Sci Rep, 9:700, https://doi.org/10.1038/s41598019- 43297-1

Caballero JD, Clark ST, Wang PW, Donaldson SL, Coburn B et al., 2018. A genome-wide association analysis reveals a potential role for recombination in the evolution of antimicrobial resistance in Burkholderia multivorans. PLoS Pathog, https://doi.org/ 10.1371/journal.ppat. 1007453

Chen X, Cheng Z, Zhang S, Werling D and Wathes DC, 2015. Combining genome wide association studies and differential gene expression data analyses identifies Candidate genes affecting mastitis caused by two different pathogens in the dairy cow. Open J Anim Sci, 5: 358-393

Clifford K, Desai D, da Costa CP, Meyer H, Klohe $\mathrm{K}$ et al., 2018. Antimicrobial resistance in livestock and poor quality veterinary medicines. Bull World Health Organ, 96(9): 662-664 
Cole JB, Wiggans GR, Ma L, Sonstegard TS, Lawlor TJ et al., 2011. Genome-wide association analysis of thirty one production, health, reproduction and body conformation traits in contemporary U.S. Holstein cows. BMC Genomics, 12: 408, https://doi.org/10.1186/ 1471-2164-12-408

Cole RK, 1968. Studies on genetic resistance to Marek's disease. Avian Dis, 12(1): 9-28

Duncan EL and Brown MA, 2018. Genome-wide Association Studies. In: Genetics of Bone Biology and Skeletal Disease- second edn. (Thakker RV, Eisman JA, Whyte MP and Igarashi T eds), Academic Press, pp33-41, https://doi.org/10.1016/ B978-0-12804182-6.00003-4

Eggen A, 2012. The development and application of genomic selection as a new breeding paradigm. Anim Front, 2(1): 10-15

Ehret GB, 2010. Genome-Wide association studies: Contribution of genomics to understanding blood pressure and essential hypertension. Curr Hypertens Rep, 12(1): 17-25

Erbe M, Hayes BJ, Matukumalli LK, Goswami S, Bowman PJ et al., 2012. Improving accuracy of genomic predictions within and between dairy cattle breeds with imputed highdensity single nucleotide polymorphism panels. J Dairy Sci, 95(7): 4114-4129

Fan B, Onteru SK, Du ZQ, Garrick DJ, Stalder KJ et al., 2011. Genome-wide association study identifies loci for body composition and structural soundness traits in pigs. PLoS ONE, 6(2): e 14726., doi:10.1371/ journal.pone.0014726

Farhat MR, Freschi L, Calderon R, Ioerger T, Snyder M et al., 2019. GWAS for quantitative resistance phenotypes in Mycobacterium tuberculosis reveals resistance genes and regulatory regions. Nat Commun, https:// doi.org/10.1038/s41467-019-10110-6
Finlay EK, Berry DP, Wickham B, Gormley EP and Bradley DG, 2012. A genome wide association scan of bovine tuberculosis susceptibility in Holstein-Friesian dairy cattle. PLoS ONE, 7(2): e30545., doi:10.1371/journal.pone.0030545

Fonseca I, Silva PV, Lange CC, Guimaraes MF, Weller MM et al., 2009. Expression profile of genes associated with mastitis in dairy cattle. Genet Mol Biol, 32(4): 776-781

Garrick DJ, Taylor JF and Fernando RL, 2009. Deregressing estimated breeding values and weighting information for genomic regression analyses. Genet Sel Evol, doi: 10.1186/1297-9686-41-55

Gerlando RD, Sutera AM, Mastrangelo S, Tolone M, Portolano B et al., 2019. Genome-wide association study between CNVs and milk production traits in Valle del Belice sheep. PLoS ONE, https://doi.org/ 10.1371/ journal.pone.0215204

Gibon JP and Bishop SC, 2005. Use of molecular markers to enhance resistance of livestock to disease: A global approach. Rev Sci Tech Off Int Epiz, 24(1): 343-353

Goddard ME and Hayes BJ, 2007. Genomic selection. J Anim Breed Genet, 124(6): 323330

Goddard ME, Kemper KE, MacLeod IM, Chamberlain AJ and Hayes BJ, 2016. Genetics of complex traits: prediction of phenotype, identification of causal polymorphisms and genetic architecture, Proc Biol Sci, doi:10.1098/rspb.2016.0569

Heringstad B, Klemetsdal G and Ruane J, 2000. Selection for mastitis resistance in dairy cattle: a review with focus on the situation in the Nordic countries. Livest Prod Sci, 64(2-3): 95-106

Heringstad B, Klemetsdal G and Steine T, 2007. 
Selection responses for disease resistance in two selection experiments with Norwegian Red cows. J Dairy Sci, 90(5): 2419-2426

Hill WG, 2012. Quantitative genetics in the genomics era. Curr Genomics, 13(3): 196206

Hirschhorn JN and Daly MJ, 2005. Genome-wide association studies for common diseases and complex traits. Nat Rev Genet, 6(2): 95-108

Huang X, Huang T, Deng W, Yan G, Qiu H et al., 2016.Genome-wide association studies identify susceptibility loci affecting respiratory disease in Chinese Erhualian pigs under natural conditions. Anim Genet, 48(1): $30-37$

Ibeagha-Awemu EM, Kgwatalala P, Ibeagha AE and Zhao X, 2008. A critical analysis of diseaseassociated DNA polymorphisms in the genes of cattle, goat, sheep and pig. Mamm Genome, 19(4): 226-245

Jiang L, Liu J, Sun D, Ma P, Ding X et al., 2010. Genome wide association studies for milk production traits in Chinese Holstein population. PLoS ONE, doi:10.1371/ journal.pone.0013661

Klein RJ, Zeiss C, Chew EY, Tsai JY, Sackler RS et al., 2005. Complement factor $\mathrm{H}$ polymorphism in age-related macular degeneration. Science, 308(5720): 385-389

Kumarasamy KK, Toleman MA, Walsh TR, Bagaria J, Butt F et al., 2010. Emergence of a new antibiotic resistance mechanism in India, Pakistan and the UK: a molecular, biological, and epidemiological study. Lancet Infect Dis, 10(9): 597-602

Kunin CM, 1993. Resistance to antimicrobial drugs- A worldwide calamity. Ann Intern Med, 118(7): 557-561

La Chevrotiere CD, Bishop SC, Arquet R, Bambou JC, Schibler L et al., 2012. Detection of quantitative trait loci for resistance to gastrointestinal nematode infections in Creole goats. Anim Genet, 43(6): 768-775

Lamont SJ, 1998. The chicken major histocompatibility complex and disease. Rev Sci Tech Off Int Epiz, 7(1): 128-142

Laxminarayan R and Chaudhury RR, 2016. Antibiotic resistance in India: Drivers and opportunities for action. PLoS Med, doi:10.1371/journal.pmed. 1001974

Lee BY, Lee KN, Lee T, Park JH, Kim SM et al., 2015a. Bovine genome-wide association study for genetic elements to resist the infection of foot-and-mouth disease in the field. Asian- Australian J Anim Sci, 28(2): 166-170

Lee YS, Jeong H, Taye M, Kim HJ, Ka S et al., 2015b. Genome-wide association study (gwas) and its application for improving the genomic estimated breeding values (GEBV) of the Berkshire pork quality traits. AsianAustral J Anim Sci, 28(11): 1551-1557

Legarra A, Robert-Granié C, Croiseau P, Guillaume $\mathrm{F}$ and Fritz S, 2011. Improved lasso for genomic selection. Genet Res, 93(1): 77-87

Liu A, Wang Y, Sahana G, Zhang G, Liu L et al., 2017. Genome-wide association studies for female fertility traits in Chinese and Nordic Holsteins. Sci Rep, doi: 10.1038/ s41598017-09170-9

Liu JJ, Liang AX, Campanile G, Plastow G, Zhang $\mathrm{C}$ et al., 2018. Genome-wide association studies to identify quantitative trait loci affecting milk production traits in water buffalo. J Dairy Sci, 101(1): 433-444

Liu RF, Bunger A and Reents R, 2004. Derivation and Calculation of approximate reliabilities and daughter yield-deviations of a random regression test- Day model for genetic evaluation of dairy cattle. J Dairy Sci, 87(6): 1896-1907 
Luo C, Qu H, Ma J, Wang J, Li C et al., 2013. Genome-wide association study of antibody response to Newcastle disease virus in chicken. BMC Genet, doi: 10.1186/14712156-14-42

Mallard BA, Wilkie BN, Kennedy BW, Gibson JP and Quniton M, 1998. Immune responsiveness in swine: Eight generations of selection for high and low immune response in Yorkshire pigs. Proceedings of the $6^{\text {th }}$ World Congress on Genetics Applied to Livestock Production, Armidale (Australia), Jan 11-16, pp257-264

Marquardt RR and Li S, 2018. Antimicrobial resistance in livestock: advances and alternatives to antibiotics. Anim Front, 8(2): 30-37

Matukumalli LK, Lawley CT, Schnabel RD, Taylor JF, Allan MF et al., 2009. Development and characterization of a high density SNP genotyping assay for cattle. PLoS ONE, doi: 10. 1371/journal.pone.0005350

Meredith BK, Berry DP, Kearney F, Finlay EK, Fahey AG et al., 2013. A genome-wide association study for somatic cell score using the Illumina high-density bovine beadchip identifies several novel QTL potentially related to mastitis susceptibility. Front Genet, doi: 10.3389/fgene.2013.00229

Meredith BK, Kearney FJ, Finlay EK, Bradley DG, Fahey AG et al., 2012. Genome-wide associations for milk production and somatic cell score in Holstein-Friesian cattle in Ireland. BMC Genet, doi: 10.1186/14712156-13-21

Meuwissen THE, Hayes BJ and Goddard ME, 2001. Prediction of total genetic value using genome-wide dense marker maps. Genetics, 157(4): 1819-1829

Minozzi G, Williams JL, Stella A, Strozzi F, Luini Met al., 2012. Meta-analysis of two genome-
Wide association studies of bovine paratuberculosis. PLoS ONE, https://doi.org/ $10.1371 /$ journal.pone.0032578

Mucha S, Bunger L and Conington J, 2015. Genome-wide association study of footrot in Texel sheep. Genet Sel Evol, doi: 10.1186/s12711-015-0119-3

Nayeri S, Schenkel F, Fleming A, Kroezen V, Sargolzaei M et al., 2019.Genome-wide association analysis for $\beta$-hydroxybutyrate concentration in milk in Holstein dairy cattle. BMC Genet, https://doi.org/10.1186/ s12863-019-0761-9

Nazari-Ghadikolaei A, Mehrabani-Yeganeh H, Miarei-Aashtiani SR, Staiger EA, Rashidi A et al., 2018. Genome-wide association studies identify Candidate genes for coat color and mohair traits in the Iranian Markhoz goat. Front Genet, doi: 10.3389/ fgene.2018.00105

Ogorevc J, Kunej T, Razpet A and Dovc P, 2009. Database of cattle candidate genes and genetic markers for milk production and mastitis. Anim Genet, 40(6): 832-851

Okamura T, Onodera W, Tayama T, Kadowaki H, Kojima-Shibata C et al., 2012. A genomewide scan for quantitative trait loci affecting respiratory disease and immune capacity in Landrace pigs. Anim Genet, 43(6): 721-729

Otto PI, Guimarães SEF, Verardo LL, Azevedo ALS, Vandenplas J et al., 2018. Genomewide association studies for tick resistance in Bos taurus $\times$ Bos indicus crossbred cattle: A deeper look into this intricate mechanism. J Dairy Sci, 101(12): 11020-11032

Ozaki K, 2002. Functional SNPs in the lymphotoxin-alpha gene those are associated with susceptibility to myocardial infarction. Nat Genet, 32(4): 650-654

Poland J and Rutkoski J, 2016. Advances and 
challenges in genomic selection for disease resistance. Annu Rev Phytopathol, 54(1) : 79-98

Reed E, Nunez S, Kulp D, Qian J, Reilly MP et al., 2015. A guide to genome-wide association analysis and post-analytic interrogation. Stat Med, 34(28): 3769-3792

Rexroad C, Vallet J, Matukumalli LK, Reecy J, Bickhart D et al., 2019. genome to phenome: improving animal health, production, and well-being - A new USDA blueprint for animal genome research 2018-2027. Front Genet, https://doi.org/ 10.3389/ fgene.2019.00327

Richards VP, Velsko IM, Alam MT, Zadoks RN, Manning SD et al., 2019. Population gene introgression and high genome plasticity for the zoonotic pathogen Streptococcus agalactiae. Mol Biol Evol, doi:10.1093/ molbev/msz169

Riggio V, Matika O, Pong-Wong R, Stear MJ and Bishop SC, 2013. Genome-wide association and regional heritability mapping to identify loci underlying variation in nematode resistance and body weight in Scottish Blackface lambs. Heredity, 110(5): 420-429

Sahana G, Guldbrandtsen B and Lund MS, 2011. Genome wide association study for calving traits in Danish and Swedish Holstein cattle. J Dairy Sci, 94(1): 479-486

Sahana G, Guldbrandtsen B, Thomsen B, Holm LE, Panitz F et al., 2014. Genome-wide association study using high-density single nucleotide polymorphism arrays and wholegenome sequences for clinical mastitis traits in dairy cattle. J Dairy Sci, 97(11): 72587275

Schmid M and Bennewitz J, 2017. Invited review: Genome-wide association analysis for quantitative traits in livestock-a selective review of statistical models and experimental designs. Arch Anim Breed, 60(3): 335-346

Sharma A, Lee JS, Dang CG, Sudrajad P, Kim HC et al., 2015. Stories and challenges of genome wide association studies in livestock -A review. Asian-Australas J Anim Sci, 28(10): 1371-1379

Stear MJ, Bairden K, Bishop S, Buitkamp C, Duncan JL et al., 1997. The genetic basis of resistance to Ostertagia circumcincta in lambs. Vet J, 154(2): 111-119

Storey JD and Tibshirani R, 2003. Statistical significance for genome wide studies. PNAS, 100(16): 9440-9445

Taneja N and Sharma M, 2019. Antimicrobial resistance in the environment: The Indian scenario. Indian J Med Res, 149(2): 119-128

Taylor DL, Zhong L, Begg DJ, de Silva K and Whittington RJ, 2008. Toll-like receptor genes are differentially expressed at the sites of infection during the progression of Johne's disease in outbred sheep. Vet Immunol Immunopathol, 124(1-2): 132-151

Thompson-Crispi KA, Sargolzaei M, Ventura R, Abo-Ismail M, Miglior F et al., 2014. A genome-wide association study of immune response traits in Canadian Holstein cattle. BMC Genomics, https://doi.org/10.1186/ 1471-2164-15-559

Toner E, Adalja A, Gronvall GK, Cicero A and Inglesby TV, 2015. Antimicrobial resistance is a global health emergency. Health Secur, 13(3): 153-155

Tsairidou S, Anacleto O, Woolliams JA and Wilson $\mathrm{AD}, 2019$. Enhancing genetic disease control by selecting for lower host infectivity and susceptibility. Heredity, 122: 742-758

Turner S, Armstrong LL, Bradford Y, Carlson CS, Crawford DC et al., 2011.Quality control 
procedures for genome-wide association studies. Curr Protoc Hum Genet, doi: 10.1002/ 0471142905.hg0119s68

Verbyla KL, Bowman PJ, Hayes BJ and Goddard ME, 2010. Sensitivity of genomic selection to using different prior distributions. BMC Proc, doi: 10.1186/1753-6561-4-S1-S5

Verbyla KL, Hayes BJ, Bowman PJ and Goddard ME, 2009. Accuracy of genomic selection using stochastic search variable selection in Australian Holstein Friesian dairy cattle, Genet Res, 91(5): 307-311

Verschoor CP, Pant SD, You Q, Schenkel FS, Kelton DF et al., 2010. Polymorphisms in the gene encoding bovine interleukin-10 receptor alpha are associated with Mycobacterium avium ssp. paratuberculosis infection status. BMC Genet, doi: 10.1186/ 1471-2156-1123

Vordermeier M, Ameni G, Berga S, Bishop R, Robertson BD et al., Aseffa, 2012. The influence of cattle breed on susceptibility to bovine tuberculosis in Ethiopia. Comp Immunol Microb, 35: 227-232

Walia K, Sharma M, Vijay S and Shome BR, 2019. Understanding policy dilemmas around antibiotic use in food animals and offering potential solutions. Indian J Med Res, 149(2): 107-118

Wang H, Misztal I, Aguilaar I, Legarra A and Muir WM, 2012. Genome-wide association mapping including phenotypes from relatives without genotypes. Genet Res (Camb), 94(2): 73-83

Wang X, Ma P, Liu J, Zhang Q, Zhang Y et al., 2015. Genome-wide association study in Chinese Holstein cows reveal two candidate genes for somatic cell score as an indicator for mastitis susceptibility. BMC Genet, doi: 10.1186/s12863-015-0263-3
Wang Y, Ding X, Tan Z, Xing K, Yang T et al., 2018. Genome wide association study for reproductive traits in a Large White pig population. Anim Genet, 49(2): 127-131

Wegener HC, 2012. Antibiotic resistance-linking human and animal health. improving food safety through a one health approach: Workshop summary. National Academies Press, Washington DC, https:// ww w.ncbi.nlm.nih.gov/books/ NBK114485/

Welderufael BG, Lovendahl P, De Koning DJ, Janss LLG and Fikse WF, 2018. Genome-wide association study for susceptibility to and recoverability from mastitis in Danish Holstein cows. Front Genet, doi: 10.3389/ fgene.2018.00141

Weller JI and Ron M, 2011. Invited review: quantitative trait nucleotide determination in the era of genomic selection. J Dairy Sci, 94(3): 1082-1090

Weller JI, 2016. Genomic Selection in Animals. John Wiley and Sons, New Jersey, United States, pp145-151

Wilkie BN and Mallard B, 2000. Genetic aspects of health and disease in pigs. In: Breeding for Disease Resistance in Farm animals, $2^{\text {nd }}$ edn., (Axford RFE, Bishop SC, Nicholas FW and Owen JB eds). CAB International, UK, pp379-396

Wilkie H, Riggio V, Matika O, Nicol L, Watt KA et $a l ., 2017$. A candidate gene approach to study nematode resistance traits in naturally infected sheep. Vet Parasitol, 243: 71-74

Wolc A, Arango J, Jankowski T, Settar P, Fulton JE et al., 2013. Genome-wide association study for Marek's disease mortality in layer chickens. Avian Dis, 57(2): 395-400

Wolfenson D, Leitner G and Lavon Y, 2015. The disruptive effects of mastitis on reproduction 
and fertility in dairy cows, Ital J Anim Sci, doi: 10.4081/ijas.2015. 4125

Woolhouse M, Ward M, Van Bunnik B and Farrar J, 2015. Antimicrobial resistance in humans, livestock and the wider environment. Phil Trans R Soc, http:// dx.doi.org/ 10.1098/ rstb.2014.0083

Wu H, Cheng D and Wang L, 2008. Association of polymorphisms of Nramp1 gene with immune function and production performance of Large White pig. J Genet Genomics, 35(2): 91-95

Wu Y, Fan H, Wang Y, Zhang L, Gao X et al., 2014. Genome-wide association studies using haplotypes and individual SNPs in Simmental cattle. PLoS ONE, doi: 10.1371/ journal.pone.0109330

Xiao L, He C, Luo L, Yang K, Yang Letal., 2019. Genome-wide association study identified genes in the response to Salmonella pullorum infection in chickens. Anim Genet, 50(4): 403-406

Yodklaew P, Koonawootrittriron S, Elzo MA, Suwanasopee T and Laodim T, 2017. Genome-wide association study for lactation characteristics, milk yield and age at first calving in a Thai multibreed dairy cattle population. Agri Natural Resour, 51(3): 223-230

Yuan Y, Caims JE, Babu R, Gowda M, Makumbi D et al., 2018. Genome-wide association mapping and genomic prediction analyses reveal the genetic architecture of grain yield and flowering time under drought and heat stress conditions in maize. Front Plant Sci, doi: 10.3389/fpls.2018.01919

Zeng P, Zhao Y, Qian C, Zhang L, Zhang R et al., 2015. Statistical analysis for genome-wide association study. The J Biomed Res, 2015, 29(4): 285-297

Zhang H, Yin L, Wang M, Yuan X and Liu X, 2019. Factors affecting the accuracy of genomic selection for agricultural economic traits in maize, cattle, and pig populations. Front Genet, https://doi.org/10.3389/ fgene.2019.00189

Zhang Z, He J, Zhang H, Gao P, Erbe Met al., 2014a. Results of genome wide association studies improve the accuracy of genomic selection. Proceedings of $10^{\text {th }}$ World Congress of Genetics Applied to Livestock Production, Vancouver (Canada), Aug 17-22, poster no. 695

Zhang Z, Ober U, Erbe M, Zhang H, Gao N et al., 2014b. Improving the accuracy of whole genome prediction for complex traits using the results of genome wide association studies. PLoS ONE, doi: 10.1371/ journal.pone.0093017

Zhu B, Li Q, Liu R, Zheng M, Wen J et al., 2019. Genome-wide association study of $\mathrm{H} / \mathrm{L}$ traits in chicken. animals, doi.org/10.3390/ ani9050260

Zvinorova PI, 2017. A genome-wide association study on mechanisms underlying genetic resistance to gastrointestinal parasites in goats. PhD Dissertation. Faculty of AgriSciences at Stellenbosch University, Zimbabwe

Article received on 03.10.2019 and accepted for publication on 26.10.2019 